\title{
EFFECT OF GUANIDINO ACETIC ACID WITH OR WITHOUT AMINO ACIDS AND FEED ENZYME ON PERFORMANCE, CARCASS CHARACTERISTICS AND ECONOMIC EFFICIENCY IN BROILERS FED A CORN/SOY- BASED DIETS
}

\author{
A.S.M. Arafa ${ }^{1}$; A.I. El-Faham ${ }^{2}$; A.G. Abdallah ${ }^{1}$ and M.H.S. El-Sanhoury ${ }^{2}$ \\ ${ }^{1}$ Dept. of Poult. Nut. Res., Anim. Prod. Res. Inst., Agric. Res. Center, Dokki, Giza, Egypt \\ ${ }^{2}$ Poultry Production Dept., Fac. of Agric., Ain Shams Univ., Egypt.
}

\section{SUMMARY}

\begin{abstract}
$\mathrm{T}$
he aim of this study was to evaluate the effect of adding Guanidino acetic acidmixture (GAA), Amino Acids (A.A.; Meth. + Lys. + Thr. + Arg.) or both (GAA + A.A.) and $\beta$-mannanase (Hemicell HT) to a typical corn soybean meal diets on growth performance, carcass characteristics and economical efficiency of broiler chicks. A total number of 225 day old Hubbard broiler chicks were classified into 5 equal groups, each was subdivided into 3 replicates with 15 chicks. The control group was fed basal (starter, grower and finisher) diets without supplementation, while the other groups $\left(\mathrm{T}_{1}\right),\left(\mathrm{T}_{2}\right),\left(\mathrm{T}_{3}\right)$ and $\left(\mathrm{T}_{4}\right)$ were fed the basal diets supplemented with $600 \mathrm{mg}$ G.A.A/kg.; $1450 \mathrm{mg}$ A.A. kg. diet or both (600mg GAA $+1450 \mathrm{mg}$ A.A.) and300mg $\beta$-mannanase/kg diet, respectively. Diets and water were provided I. throughout the experimental period (1-35) days of age. The results indicated that: Live body weight, daily weight gain and daily feed intake for the broiler chicks fed basal diets supplemented with GAA + A.A., $\left(\mathrm{T}_{3}\right)$ or $\beta$-mannanase, $\left(\mathrm{T}_{4}\right)$ reflected the highest significant results than those fed control basal diets at 1-35 days of age. Chicks fed $T_{1}, T_{2}$ and $T_{3}$ diets had significant better FCR compared with those fed control or $\mathrm{T}_{4}$ diets. The best protein (PCR), energy (ECR) conversion ratio and the highest performance index (PI) and production efficiency factor (PEF) were recorded for the group supplied with GAA + A.A., $\left(\mathrm{T}_{3}\right)$ compared with other dietary treatments. The group of chicks fed AA mixture recorded significantly higher percentages of dressing and ready to look comparing to control group. While, the same group $\left(\mathrm{T}_{2}\right)$ showed lower value of giblets $\%$ as comparing to unsupplemented treatment. Economical evaluation, the chicks fed basal diets supplemented with different feed additives $\left(\mathrm{T}_{1-4}\right)$ supported the calculated economic efficiency percentages compared to control group and the corresponding increasing values were $15.73,1.35,35.89$ and $14.14 \%$ respectively.
\end{abstract}

Keywords: CreAmino, Amino Acids, B-mannanase, broiler and economic efficiency.

\section{INTRODUCTION}

Guanidine acetic acid (GAA) is considered as the only immediate precursor for creatine in the body of animals. Moreover, it is more stable and less expensive than creatine and it could make a good additive for poultry Joroslav et al. (2014) and Mousavi et al. (2013).

In Egypt, poultry feed is consisting mainly of corn and soybean meal and there is a ban of animal by-product use in poultry industry. Therefore, poultry feed might be a deficiency in the semi-nutrient, creatine, since corn and soybean (plant origin) are lacking in this nutrient (Ringet et al., 2007) and among be thus deficient in all- vegetable diets. GAA as a creatine source is more stable and less expensive than creatine itself (Baker, 2009). Moreover, GAA could be beneficial in broiler diets, because it may be able to spare arginine, which is considered as the fifth limiting amino acid in typical corn-soybean diets for broilers (Dilger et al., 2013) and GAA play central roles in energy metabolism (Lemme et al. 2007b and 2010). Recently, (Michiels et al. 2012 and Mousavi et al., 2013) suggested that supplementing GAA tovegetable diets improves broilers performance and carcass characteristics as well as improve FCR and energy efficiency.

On the other hand, formulating diets based on amino acids allowed nutritionists to formulate diets closer to the various classes of poultry requirement, thereby reducing waste and cost has been the subject of numerous investigation. 
However, due to technological advances some essential amino acids (Methionine (Meth.), Lysine (Lys.), Thereonine (Thr.) and Arginine (Arg.)) have become commercially available in recent years and there is a good possibility that others will be available in the future. DL-methionine is normally considered to be the first limiting amino acid (LAA) in poultry diets. In general, amino acids balance and nitrogen retention are improved by methionine supplementation. However, supplementation of lysine (Second, LAA) and methionine to practical poultry diets improved production performance, only if no other amino acid is limiting (Harms and Ivey, 1993). Additionally, formulating broiler diets to be adequate in threonine (Third, LAA) is relatively critical, because therionine deficiency may decrease efficiency of lysine utilization. Lysine and threonine have been shown to interact in such a way that broiler body weight gain and breast fillet yields are increased (Canogullari et al. 2009 and Baylan et al. 2006). Additionally, Barkley and Wallis (2001) observed that, increasing dietary threonine concentration to $7.29 / \mathrm{kg}$ improved growth performance and feed conversion ratio of broilers.

In addition, it is well documented that enzyme supplementation in poultry diets can improve efficiency of converting low- quality protein feedstuffs into high-quality broiler meat protein for humans (Bedford and Morgan, 1996). Daskiran et al. (2004) reported that B-mannanase improved feed: gain, water: feed ratio and total dry fecal output of broilers by degrading B-mannans. Jackson et al. (2004) demonstrated that B-mannanase inclusion at 80 million units per tonne improved both body weight gains and feed conversion of broilers fed corn/soybean diets.

Therefore, the objective of the present study was to evaluate the efficacy of a supplementing GAA, mixture of Amino Acids (Meth. + Lys. + Thr. + Argi) or both (GAA + AA) and $\beta$-mannanase (trade name Hemicell HT®, Elanco) to corn soybean meal diets, on performance, carcass characteristics and economic efficiency of broiler chickens from 1 to 35 days of age.

\title{
MATERIALS AND METHODS
}

\section{Materials:}

\author{
a- Cre AMINO: Contains 94\% Guanidine Acetic Acid (GAA), and purchased from Evonik \\ Industries. \\ b- Methionine \\ Lysine \\ Thrionine \\ Arginine \\ c- $\quad \beta$-mannanase: -Hemicell HT®
}

\section{Birds, Diets and treatments:}

A total of 225, day - old Hubbard male broiler chicks were obtained from a commercial hatchery. Chicks were housed in battery cages and divided equally into 5 groups of 45 chicks in 3 replications, 15 bird each.. Birds were vaccinated for Newcastle disease virus ond 8 and 18, for infections bronchitis on $\mathrm{d} 1$ and 14, and for Gumboro disease on d 15 and 24. Chicks were fed conrn-soybean based diets during the starter (1-4 days), grower (15-28 days) and finisher (29-35 days old) phases of growth.

The experiment consisted of 5 dietary treatments as follow:

1- Control (C), corn-soybean-based diet.

2- C supplemented with $600 \mathrm{mg} \mathrm{GAA} / \mathrm{kg}$ diet.

3- C supplemented with mixture of amino acids (250mg Meth. +600mg Lys. + $400 \mathrm{mg}$ Thyr. + 200mgArgi) $/ \mathrm{kg}$ diet.

4- C supplemented with (600mg GAA +250mg Meth. +600mg lys. + 400mg thre. + 200mg Argi) $/ \mathrm{kg}$ diet.

5- C supplemented with $300 \mathrm{mg} \beta$-mannanase / $\mathrm{kg}$ diet.

Feed and water offered ad libitum all over the experimental period and experimental diets were formulated to meet the NRC (1994) nutritional recommendations for broilers as presented in Table (1).

\section{Measurements:}

Measurements of live body weight and daily feed intake were recorded at the end of experimental period (35 d) daily weight gain and feed conversion ratio were calculated during whole experimental period. The protein (PCR) and energy (ECR) conversion ratio were calculated during experimental period. Performance index according to North (1981) and production efficiency factor according to Emmert (2000) were also calculated. At day 35, four birds per reatment were selected for calculation of 
dressing percentage and ready to cook parentage. The percentages of liver, heart gizzard and giblets were calculated on the basis of live body weight.

\section{Economical efficiency:}

At the end of the study, economical efficiency for live weight was expressed as broiler-production throughout the study and calculated using the following equation:

Economical efficiency $(\%)=($ Net return LE/total feed cost LE) $\times 100$

Where:

Net return $=$ Total return - the cost of feeding.

\section{Statistical Analysis:}

The statistical analysis for the Data were performed by using the general linear model (GLM) procedures according to SAS (2004) and the significant mean differences among treatments means were determined using Duncan's Multiple Rang test (Ducan, 1955).

The statistical model was:

Where:

$$
\text { Yij }=\mu+\mathrm{Ti}+\text { eij }
$$

Yij: observation of the parameter measured, $\mu$ : overall mean, Ti: effect of treatment (i: 1 to 6) and eij: random error.

\section{RESULTS AND DISCUSSION}

\section{Productive performance:}

\section{Live body weight (g) and daily weight gain (g/day):}

The live body weight $(\mathrm{g})$ at $35 \mathrm{~d}$ of age and daily weight gain ( $\mathrm{g} /$ day) of broilers as affected by dietary treatments are illustrated in Table (2). It is worth to note that, the chicks fed (CreAmino + A.A., $\mathrm{T}_{3}$ ) and ( $\beta$-mannanase, $\mathrm{T}_{4}$ ) diets during overall period (1-35 days) reflected the highest significant $(\mathrm{P}<0.01)$ results in both live body weight and daily weight gain compared with other treatments either control, $\mathrm{T} 1$ or $\mathrm{T} 2$. The enhancement in $\mathrm{T} 3$ and $\mathrm{T} 4$ was $27.5 \%$ and $9.7 \%$, respectively compared with the control group. On the other hand, chicks fed basal diet + GAA, $\left(\mathrm{T}_{1}\right)$ showed increasing in body weight and daily weight gain being (4.5\%) compared to those fed control basal diet (1911.67 versus $18630.0, \mathrm{~g}$ and 53.47 versus $51.14 \mathrm{~g} / \mathrm{day})$ respectively the differences were statistically none significant. In addition, chicks fed basal diet + A.A. $\left(\mathrm{T}_{2}\right)$ showed the lowest body weight and daily weight gain being compared with the control group and other groups. The reduction was $1.5 \%$ comparing to control without significant differences as shown in Table (2).

\section{Daily feed intake and feed conversion ratio:}

Result present in Table (2) indicate that daily feed intake per chick (g/day) was significantly $(\mathrm{P}<0.01)$ increased by feeding GAA + A.A., $\left(\mathrm{T}_{3}\right)$ and $\beta$-mannanase, $\left.\mathrm{T}_{4}\right)$ diets compared with those fed other dietary treatments and the corresponding values were $84.01 \mathrm{~g}(\mathrm{c}), 84.04 \mathrm{~g}\left(\mathrm{~T}_{1}\right)$ and $79.57 \mathrm{~g}\left(\mathrm{~T}_{2}\right)$ versus $102.97 \mathrm{~g}\left(\mathrm{~T}_{3}\right)$ and $191.06 \mathrm{~g}\left(\mathrm{~T}_{4}\right)$ respectively.

Increasing daily feed consumption $(\mathrm{g} / \mathrm{d})$ could be related to the fact that broiler chicks consume more feed to meet energy requirements; moreover genetically, broiler chicks require more dietary energy to maximize growth during short rearing periods. According to Scott and Neshein (1982) and Lesson and Summers (1991) birds have the ability to meet their energy requirements to certain extent by increasing feed consumption.

Feed conversion ratio (FCR) show the same trend since experimental treatments with different feed additives from $T_{1}-T_{3}$ gave significant compared with control. The values of FCR indicated significant differences between birds fed diets containing GAA, $\left(T_{1}\right)$; A.A., $\left(T_{2}\right)$ or both GAA + A.A. $\left(T_{3}\right)$ compared with those fed control or $\left(\mathrm{T}_{4}\right)$ diets. The best FCR was detected for the chicks fed diets incorporated with GAA $\left(\mathrm{T}_{1}, 1.55\right)$ or A.A. $\left(\mathrm{T}_{2}, 1.58\right)$ or both $\left(\mathrm{T}_{3}, 1.57\right)$. On the other hand, the worst FCR were found in chicks fed $\left(\mathrm{T}_{4}, 1.62\right)$ or control (1.64) diets, which could be due to the lowest daily weight gain and higher daily feed intake (Table 2). Growth rate: Table (2) shows the effect of different experimental treatments on growth rate for chicks during experimental period (1-35) days of age. It was 


\section{Arafa et al.}

clearly noted that inclusion different feed additives in chicks diets, except $T_{3}$ had no significant effect on growth rate. The corresponding values for growth rate ranged between 1.91 and 1.93. On the other hand, the chicks fed control diet gave the lowest figure, while chicks fed $\mathrm{T}_{3}$ diets gave the highest figure and the differences were significant.

Similar observations were reported by other investigators, Lemme et al. (2007a), Michiels et al. (2012) in broiler chicks and Lemme et al. (2010) in turkeys. They concluded that supplementing GAA (CreAmino) in all-vegetable diets improves performance and significantly improved feed conversion ratio and efficiency of AME. On the other hand, dietary ME levels could be adjusted in small increments to lower the cost of feed without jeoparding the performane, so based on that, it is recommended to lower the $\mathrm{ME}$ level by $50 \mathrm{kcal} / \mathrm{kg}$ for each growing period and supplement diets with GAA (Alaeldin et al., 2014). On the same order, Hassan et al. (2003) and Abdalla et al. (2005) found insignificant difference on final body weight by increasing dietary methionine level in Mandarah strain. Also, Abdalla et al. (2005) came to the same conclusion in Gimmizah strain..

On the other hand, the results were consistent with the findings of Jackson et al. (2004), Zou et al. (2006) and Kong et al. (2011), who reported that supplemented B-mannanse improved weight gain of broilers fed different level of B-mannanase with corn-soybean meal based diets.

Protein (PCR), energy (ECR) conversion ratio; performance index (PI) and Production Efficiency Factor (PEF)

Results listed in Table (3) show the effect of GAA, AA. or $\beta$-mannanase supplementation to control basal diets on PCR, ECR, PI and PEF during whole experimental period (1-35 days of age). It was clearly noted that inclusion different feed additives in chicks diets (from $\mathrm{T}_{1}-\mathrm{T}_{4}$ ) had significant effect on studied parameters (PCR, ECR, PI and PEF). The corresponding values for PCR ranged between 0.33 and 0.35 . While ECR values varied between 4.92 and 5.36, performance index (PI) values ranged between 111.41 and 148.48. While those of PEF ranged between 318.32 and 424.23 and differences between treatments were significant $(\mathrm{P}<0.01)$. On the other hand, the worst PCR and ECR values were detected for the chicks fed control diets ( 0.35 and 5.36) respectively.

However, the best values were found in chicks fed diets incorporated with GAA + A.A., $\left(\mathrm{T}_{3}\right)$ and the corresponding rates being 0.32 and 4.92 respectively and in most cases differences between treatments were significant. In the same order, performance index (PI) and (PEF) values showed the same trend, in which $\left(\mathrm{T}_{3}\right)$ treatment reflected the highest figures compared with other treatments and the corresponding figures being 148.48 and 424.23 respectively. While, chicks fed control diets had the lowest figures being (111.41 and 318.32) respectively and differences among treatments were significant. These results are in agreement with several reports demonstrating that positive impact on bird performance and energy utilization of supplementing the diet with GAA (Michielset al. 2012), Amino acids (El-Faham and Ibrahim, 2004) and $\beta$-mannanase (Kong et al. 2011).

Carcass characteristics

Table (4) shows the effect of different treatments on carcass characteristics at the end of 35 days of age. Experimental treatments with different feed additives from $\mathrm{T}_{1}-\mathrm{T}_{4}$ had significant effect on most studied parameters (Dressed carcass \%, Giblets \% and Ready to Cook \%) compared with control. The corresponding values for dressing percentages ranged between $70.41 \%$ and $74.28 \%$, while giblets percentages ranged between $4.33 \%$ and $5.32 \%$, while ready to cook percentages ranged between $75.74 \%$ and $78.62 \%$. On the other hand, the chicks fed A.A. diets, $\left(\mathrm{T}_{2}\right)$ gave the highest values for dressing and ready to cook $\%$ and reflected the lowest rate for giblets $\%$ compared with those fed control diets.

Moreover chicks fed control diets showed the highest liver \% (2.88\%) and chicks fed A.A. diets $\left(\mathrm{T}_{2}\right)$ gave the highest heart \% $(0.55 \%)$. The differences among treatments were not significant.

Similar results have been reported by Elamin and Abbas (2011); Abudabos and Aljumaah (2012); Rattana et al. (2011) and Nasr and Kheiri (2011) they concluded that higher amino acids density levels had a beneficial effect on carcass characteristics of broiler chicks.

Economical evaluation

Data for economical evaluation are summarized in Table (5 and 6). The economical evaluation were calculated according to the input-output, economical efficiency and relative economical efficiency. The price for fed ingredients and selling price of live broiler chicks in Egypt, during March 2017. The average cost/ton of final experimental diets, starter, grower and finisher $\left(T_{1}-T_{4}\right)$ relatively increased the cost final diets compared with the control Table (5). Thus differences could be explained on the basis that feed additives (GAA, A.A. and $\beta$-mannanase) treatments raised the feed cost as compared to control basal diets and the corresponding increasing values were $0.7,2.0,2.7$ and $0.5 \%$ respectively.

As shown in Table (6), It's interesting to state that under the condition of the present study, the chicks fed control basal diets supplemented with different feed additives $\left(\mathrm{T}_{1}-\mathrm{T}_{4}\right)$ supported the calculated economical efficiency \% of chicks and the corresponding increasing were $15.73,1.35,35.89$ 
and $14.14 \%$ respectively, similar observations have been reported by Roland et al. (2000); Liu et al. (2005) Onu et al. (2010); Selim et al. (2016). They concluded that, economic analysis revealed that different feed additives supplementation of broiler diets were more profitable than feeding unsupplemented diets.

\section{CONCLUSION}

From the present study, it could be concludedthat supplemental basal diet during starter, grower and finisher with $600 \mathrm{mg}$ GAA+ $1450 \mathrm{mg}$ A.A. mixture $/ \mathrm{kg}$ diet would have a positive effects on productive performance and economical efficiency of broiler chicks without adverse effect on carcass characteristics.

\section{REFERENCES}

Abdalla, A.; H.M. Yakout and M.M. Khalifah (2005). Determination of lysine and methionine requirements of Gimmizah strain during egg production stage. $3^{\text {rd }}$ international Poult. Conf., 4-7 Apr. Hurghada- Egypt.

Alaeldein, M.A.; F. Saheh; A. Lemme and Hana, A.H. Zakaria (2014). The relationship between guanidine acetic acid and dietary metabolizable energy level on broiler, S performance. J. of food, Agr. \& Eniv. 12: 648-654.

Bakr, D.H. (2009). Advances in protein-amino acid nutrition of poultry. Amino Acids 37: 29-41.

Barkley, G.R. and I.R. Wallis (2001). Threonine requirements of broiler chickens: an experimental validation of a model using growth responses and carcass analysis. Br. Poult. Sci. 42: 616-624.

Baylan, M.; S. Canogullari; T. Ayasan and A. Sahin (2006). Dietary threonine supplementation for improving growth performance and edible carcass parts in Japanese quails, Coturnix coturnix Japonica. Int. J. Poult. Sci. 5: 635-638.

Bedford, M.R. and A.J. Morgan, (1996). The use of enzymes in poultry diets. World's Poult. Sci. J. 52: 61-68.

Canogullari S.; M. Baylan and T. Ayasan (2009). Threonine requirement of laying Japanese quails. J. Anim. Vet. Adv. 8(8): 1539-1541.

Daskiran, M.; R.G. Teeter; D.W. Fodge and H.Y. Hasiao (2004). An evaluation of endo-B-Dmannanase (Hemicall) effects on broiler performance and energy use in diets varying in Bmannanase content. Poultr. Sci. 83: 662-668.

Dilger, R.N.; K. Bryant-Angeloni; R.L. Payne; A. Lemme and C.M. Parsons (2013). Dietary guanidine acetic acid is an efficacious replacement for arginine four young chicks. Poult. Sci. 92: 171-177.

Duncan, D.B. (1955). Multiple ranges and multiple F test. Biometrics, 11: 1-42.

Elamin, M.A. and T.E. Abbas (2011). Effects of dietary levels of methionine on broiler performance and carcass characteristics. Int. J. Poult. Sci., 10: 147-151.

El-Faham, A.I. and Manar, T. Ibrahim (2004). Effect of enzyme supplementation on performance, meat quality and economic evaluation on broiler chicks fed low protein diets. Annals of Agric. Sc. Moshtohot. 42: 1009-1026.

Harms, R.H. and F.J. Ivey (1993). Performance of commercial laying hens fed various supplemental amino acids in corn-soybean meal diet. J. Appl. Poult. Res. 2: 273-282.

Hassan, R.A.; E.H. El-Ganzoury; F.A. Abd El-Ghany and M.A. Shata (2003). Influence of dietary zinc supplementation with Methionine or phytase enzyme on productive and reproductive performance for Mandarah strain. Egypt. Poult. Sci., 23: 761-785.

Jackson, M.E.; K. Geronian; A. Knox; J. Menab and E. Mecartney (2004). A dose-response study with the feed enzyme $\beta$-mannanase in broilers provided with corn-soybean meal based diets in the absence of antibiotic. Poult. Sci. 83: 1992-1996.

Jaroslav, H.; J. Zelenka; V. Machander; C. de la Cruz; M. Lestak and D. Hampel (2014). Effects of guanidine acetic acid supplementation to broiler diets with varying energy content. Acta Univ. Agric. Et Silvic. Mende. Brune. 62(3): 477-485. 


\section{Arafa et al.}

Kong, C.; J.; H. Lee and A. Adeola (2011). Supplementation of $\beta$-mannanase to starter and grower diets for broilers. Can. J. Anim. Sci.: 91: 389-397.

Lemme A.; J. Ringel; H.S. Rostagno and M.S. Redshaw (2007). Supplemental guanidino acetic acid improved feed conversion, whight gain and breast meat yield in male and female broilers. World's Poult. Sci.; 335-338.

Lemme, A.; J. Ringel; S. Sterk and J.F. Young (2007b). Supplemental guanidine acetic acid affects energy metabolism of broilers. pp 339-342 in proc. $16^{\text {th }}$ Eur. Symp. Poult. Nutr. Strasbourg, France. World's Poult. Sci. Assoc., Beekbergen, the Netherlands.

Lemme, A.; R. Gobbi; A. Helmbrecht; J.D. Van Der Klis; J. Firman; J. Jankowski and K. Kozlowski (2010). Use of guanidine acetic acid in all-vegetable diets for turkeys. Proceedings of the $4^{\text {th }}$ turkey Sci. Prod. Conf. Macclesfield, UK, pp 57-61.

Lui, Z.; G. Wu; M.M. Bryant and D.A. Roland-Sr. (2005). Influence of added synthetic lysin in lowprotein diets with the methionine plus cysteine to lysine ratio maintained at $0.75 \mathrm{~J}$.A. Appl. Poult. Res. 14: 174-182.

Michiels, J.; L. Maertens; J. Buyse; A. Lemme; M. Rademacher; N.A. Dierick and S. Desmet (2012). Supplementation of guanidinoacetic acid to broiler diets: Effects of performance, carcass characteristics, meat quality and energy metabolism. Poult. Sci.: 91: 402-412.

Mousavi, S.N.; A. Afsar and H. Lotfollahian (2013). Effects of guanidine acetic acid supplementation to broiler diets with varying energy contents. J. Appl. Poult. Res. 22: 47-54.

Nasr, J., and F. Kheiri (2011). Effects of different levels of lysine an carcass yields and composition in broiler. Res. Opin. Anim. Vet. Sci. 10: 655-661.

Selim, Nessrin A.; Heba H. Habib; Hemat A.Abdel Mageed; Amany H. Waly; A.A. Fadl and S.M. Shalash (2016). Egypt. Poult. Sci. 36: 233-249.

North, M.O. and D.D. Bell (1981). Breeder Management. In: "Commercial Chicken Production Manual". 4th Ed., Van Nostrand Reinhold. New York, USA.

NRC (1994). National Research Council. Nutrient Requirements of poultry. $9^{\text {th }}$ Ed. Composition of poultry feedstuffs. National Academy Press, Washington, DC, USA. P.P. 61-75.

Onu P.N.; M.C.A. Yo-Enwerm and E.O. Ahaotu (2010). Evaluation of carcass characteristics and cost effectiveness of broiler chicks fed synthetic lysine and methionine supplemented soybean-based diets. I.J.S.N. 1: 22-26.

Rattana, N.; C. Bunchasak; M. Kanchana; C. Apassari; P. Somkiert and L. Wiriya (2011). Effects of methionine supplementation in low protein diets subsequent re-feeding on growth performance, liver and serum lipid profile, body composition and carcass quality of broiler chickens at 42 days of age. J. Poult. Sci., 48: 229-238.

Ringel, J.; A. Lemme; A. Knox; J. Mc Nab and M.S. Redshaw (2007). Effects of graded levels of creatine and guanidine acetic acid in vegetable based diets on performance and biochemical parameters in muscle tissue. In: proceedings of the $16^{\text {th }}$ European Symp. on Poultr. Nutr. France: World's Poult. Sci. 387-390.

Roland, Sr. D.A.; M.M. Bryant; J.X. Zhang; S.K. Rao and J. Self (2000). Econometric feeding andmanagement of commercial Leghorons: Optimizing profits using new technology. P. 463-472 in egg nutrition and Biotechnology. J.S. Sim., S. Nakai, and W.Guenter, ed. CAB1 publishing, CAB Int., Wallingbord, UK.

SAS (2004). SAS procedure guide version 6. $12^{\text {th }}$ Ed. SAS institute Inc., Cary, NC, and U.C.A.

Zou, X.T.; X.J. Qiao and Z.R. Xu (2006). Effect of $\beta$-mannanase (Hemicell) on growth performance and immunity of broilers. Poult. Sci. 85: 2176- 2179. 
تأثير جوانيدو استيك مع أو بدون الأحماض الأمينية وإضافة الإنزيمات على الأداء الإنتاجى وصفات الأبيحة والكفاءة الاقتصادية لاجاج التسمين المغذى على علائق أذرة ـ صويا لأنيات

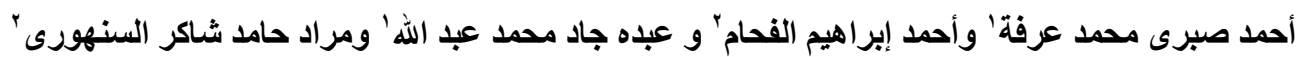

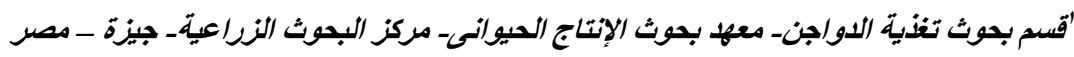

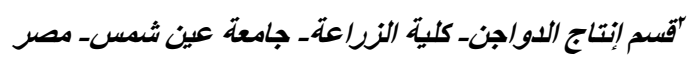

أجريت تجربة تقييم الأداء الإنتاجى وصفات الذبيحة والعائد الاقتصادى لبدارى التسمين (هبرد) المغذى على علائق نباتئة مضاف

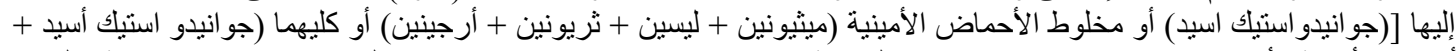

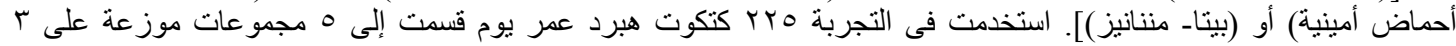
مكررات (10 طائر /مكرر).

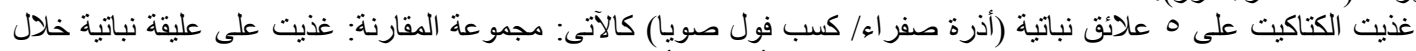

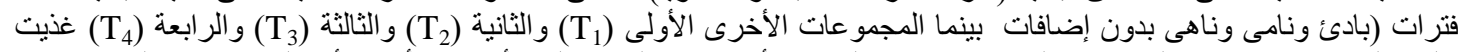

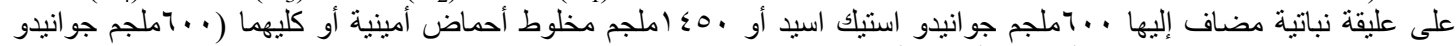

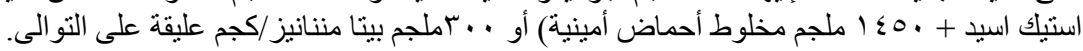

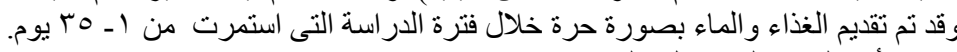

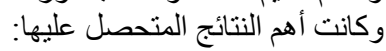

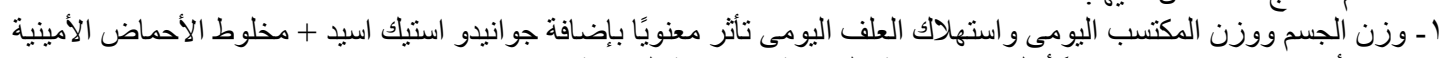

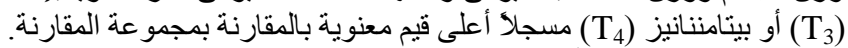

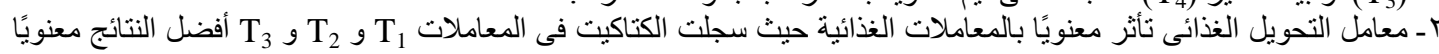

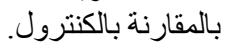

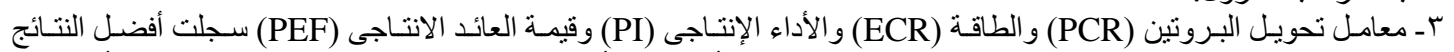

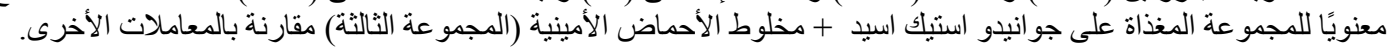

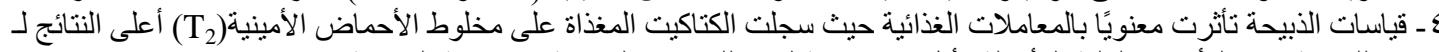

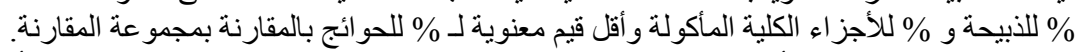

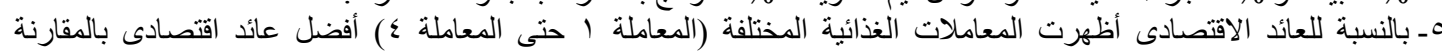

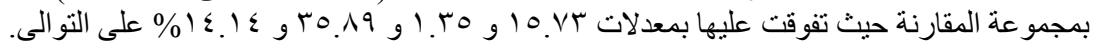

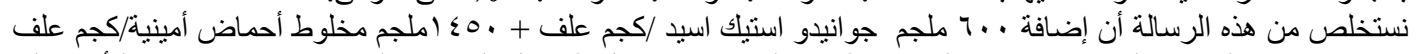

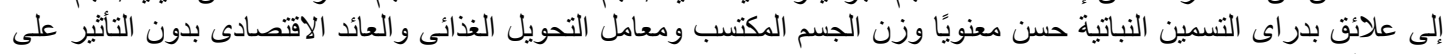
صفات الذيحة. 
Table (1): Feed ingredients and calculated analyses of experimental basal diets.

\begin{tabular}{lccc}
\hline \multicolumn{1}{c}{ Ingredients } & \multicolumn{3}{c}{ Experimental Basal Diets } \\
\cline { 2 - 4 } & Starter (1-14) d & Grower (15-28) d & Finisher (29-35) d \\
\hline Yellow Corn & 51.55 & 57.23 & 62.59 \\
Soybean meal 44\% & 35.00 & 29.79 & 24.70 \\
Corn Gluten Meal 60\% & 5.20 & 4.90 & 4.60 \\
Limestone $\left(\mathrm{CaCO}_{3}\right)$ & 1.35 & 1.10 & 1.08 \\
Di-Ca Phosphate & 1.90 & 1.68 & 1.55 \\
Salt (NaCl) & 0.40 & 0.40 & 0.40 \\
Premix* & 0.30 & 0.30 & 0.30 \\
Soy Oil & 3.50 & 4.00 & 4.25 \\
DL-Methionine & 0.31 & 0.24 & 0.21 \\
Lysine - HCl & 0.32 & 0.25 & 0.23 \\
Anti-Oxidant & 0.17 & 0.11 & 0.09 \\
Total & 100 & 100 & 100 \\
Calculated analysis & & & 19.04 \\
Crude Protein \% & & 21.01 & 3238 \\
ME Kcal/ Kg diet & 23.01 & 3159 & 0.85 \\
Calcium \% & 3046 & 0.90 & 0.42 \\
Available Phosphorus \% & 1.07 & 0.45 & 1.10 \\
Lysine \% & 0.51 & 1.25 & 0.54 \\
Methionine \& Cysteine \% & 1.45 & 0.60 & 6199 \\
Price/ Ton (L.E.) & 0.69 & 6449 & . \\
\hline
\end{tabular}

Each 3 Kg of premix contains: Vit. A: 12000000 IU; Vit. D3 2000000 IU; Vit. E: 10000 mg; Vit. K3: 2000 mg; Vit. B1:1000 mg; B2: $5000 \mathrm{mg}$; B6:1500 mg; B12: $10 \mathrm{mg}$; Biotin: $50 \mathrm{mg}$; Choline chloride: $250000 \mathrm{mg}$; Pantothenic acid: $10000 \mathrm{mg}$; Nicotinic acid: $30000 \mathrm{mg}$; Folic acid: $1000 \mathrm{mg}$; Mn: $60000 \mathrm{mg}$; Zn: $50000 \mathrm{mg}$; Fe: $30000 \mathrm{mg}$; Cu: $10000 \mathrm{mg}$; : $1000 \mathrm{mg}$; Se: $100 \mathrm{mg}$ and Co: $100 \mathrm{mg}$.

Table (2): Effect of different dietary treatments on productive performance.

\begin{tabular}{|c|c|c|c|c|c|c|}
\hline \multirow{2}{*}{ Items } & \multicolumn{6}{|c|}{ Dietary Treatments } \\
\hline & Control & $\mathrm{T}_{1}$ & $\mathrm{~T}_{2}$ & $\mathrm{~T}_{3}$ & $\mathrm{~T}_{4}$ & Sig. \\
\hline Live body weight (g) & $1830.00^{\mathrm{cd}}$ & $1911.67^{\mathrm{c}}$ & $1803.33^{\mathrm{d}}$ & $2333.33^{\mathrm{a}}$ & $2006.67^{b}$ & $* *$ \\
\hline $\begin{array}{l}\text { Daily weight gain } \\
\text { (g/ day) }\end{array}$ & $\begin{array}{l}51.14^{\mathrm{cd}} \\
\pm 1.34\end{array}$ & $\begin{array}{l}53.47^{\mathrm{c}} \\
\pm 0.61\end{array}$ & $\begin{array}{l}50.38^{\mathrm{d}} \\
\pm 0.65\end{array}$ & $\begin{array}{l} \pm 29.05 \\
65.52^{\mathrm{a}} \\
\pm 0.83\end{array}$ & $\begin{array}{l} \pm 20.48 \\
56.19^{b} \\
\pm 0.58\end{array}$ & $* *$ \\
\hline $\begin{array}{l}\text { Daily Feed intake } \\
\text { (g/ day) }\end{array}$ & $\begin{array}{l}84.01^{\mathrm{c}} \\
\pm 2.03\end{array}$ & $\begin{array}{l}84.04^{\mathrm{c}} \\
\pm 1.90\end{array}$ & $\begin{array}{l}79.57^{\mathrm{c}} \\
\pm 1.26\end{array}$ & $\begin{array}{c}102.97^{\mathrm{a}} \\
\pm 1.43\end{array}$ & $\begin{array}{l}91.06^{\mathrm{b}} \\
\pm 2.01\end{array}$ & $* *$ \\
\hline $\begin{array}{l}\text { Feed conversion ratio } \\
\text { (feed/ gain) }\end{array}$ & $\begin{array}{l}1.64^{\mathrm{a}} \\
\pm 0.01\end{array}$ & $\begin{array}{l}1.55^{b} \\
\pm 0.01\end{array}$ & $\begin{array}{l}1.58^{b} \\
\pm 0.01\end{array}$ & $\begin{array}{l}1.57^{\mathrm{b}} \\
\pm 0.01\end{array}$ & $\begin{array}{r}1.62^{\mathrm{a}} \\
\pm 0.01\end{array}$ & $* *$ \\
\hline Growth rate & $\begin{array}{l}1.91^{\mathrm{b}} \\
\pm 0.01\end{array}$ & $\begin{array}{l}1.92^{\mathrm{b}} \\
\pm 0.01\end{array}$ & $\begin{array}{l}1.91^{\mathrm{b}} \\
\pm 0.01\end{array}$ & $\begin{array}{l}1.93^{\mathrm{a}} \\
\pm 0.01\end{array}$ & $\begin{array}{l}1.92^{\mathrm{b}} \\
\pm 0.01\end{array}$ & $* *$ \\
\hline
\end{tabular}

$a, b, c, d$ Means within the same row with different superscripts are significantly different. Sig. $=$ Significance, $* *$ $(P \leq 0.01)$

" $1-\operatorname{control}(C) . \quad$ 2- $C+G A A\left(T_{1}\right) . \quad$ 3-C+ AA. $\left(T_{2}\right) . \quad 4-G A A+A \cdot A .\left(T_{3}\right) \quad$ 5- $C+\beta$-mananase $\left(T_{4}\right)$ 
Table (3): Effect of different dietary treatments on PCR, ECR, PI and PEF.

\begin{tabular}{|c|c|c|c|c|c|c|}
\hline \multirow{2}{*}{ Items } & \multicolumn{6}{|c|}{ Dietary Treatments } \\
\hline & Control & $\mathrm{T}_{1}$ & $\mathrm{~T}_{2}$ & $\mathrm{~T}_{3}$ & $\mathrm{~T}_{4}$ & Sig. \\
\hline \multirow{2}{*}{$\begin{array}{l}\text { PCR: Protein conversion ratio } \\
\text { (g protein/g gain) }\end{array}$} & $0.35^{\mathrm{a}}$ & $0.33^{\mathrm{bc}}$ & $0.33^{\mathrm{b}}$ & $0.32^{\mathrm{c}}$ & $0.34^{\mathrm{b}}$ & \multirow{2}{*}{$* *$} \\
\hline & \pm 0.01 & \pm 0.01 & \pm 0.01 & \pm 0.01 & \pm 0.01 & \\
\hline \multirow{2}{*}{$\begin{array}{l}\text { ECR: Energy conversion ratio } \\
\text { (Kcal/g gain) }\end{array}$} & $5.36^{\mathrm{a}}$ & $5.04^{\text {bc }}$ & $5.15^{\mathrm{b}}$ & $4.92^{\mathrm{c}}$ & $5.19^{b}$ & \multirow{2}{*}{$* *$} \\
\hline & \pm 0.08 & \pm 0.05 & \pm 0.01 & \pm 0.01 & \pm 0.04 & \\
\hline \multirow{2}{*}{ Performance Index ${ }^{1}(\mathrm{PI})$} & $111.41^{\mathrm{c}}$ & $123.13^{b}$ & $114.18^{\mathrm{c}}$ & $148.48^{\mathrm{a}}$ & $123.85^{b}$ & \multirow{2}{*}{$* *$} \\
\hline & \pm 3.35 & \pm 0.59 & \pm 1.14 & \pm 1.67 & \pm 0.28 & \\
\hline \multirow{2}{*}{$\begin{array}{l}\text { Production Efficiency Factor }{ }^{2} \\
\text { (PEF) }\end{array}$} & $318.32^{c}$ & $351.80^{b}$ & $326.23^{c}$ & $424.23^{\mathrm{a}}$ & $353.87^{b}$ & \multirow{2}{*}{$* *$} \\
\hline & \pm 9.59 & \pm 1.70 & \pm 3.27 & \pm 4.79 & \pm 0.82 & \\
\hline
\end{tabular}

$a, b, c$ Means within the same row with different superscripts are significantly different. Sig. = Significance $* *$

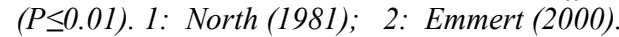

"1- control $(C) . \quad$ 2-C+GAA $\left(T_{1}\right) . \quad 3-C+A A .\left(T_{2}\right) . \quad 4-G A A+A . A .\left(T_{3}\right) \quad$ 5- $C+\beta$-mananase $\left(T_{4}\right)$

Table (4): Effect of dietary treatments on some carcass characteristics.

\begin{tabular}{|c|c|c|c|c|c|c|}
\hline \multirow{2}{*}{ Items } & \multicolumn{6}{|c|}{ Dietary Treatments } \\
\hline & Control & $\mathrm{T}_{1}$ & $\mathrm{~T}_{2}$ & $\mathrm{~T}_{3}$ & $\mathrm{~T}_{4}$ & Sig. \\
\hline Dressed carcass \% & $70.41^{b} \pm 0.67$ & $71.57^{b} \pm 1.26$ & $74.28^{\mathrm{a}} \pm 0.31$ & $71.29^{b} \pm 0.72$ & $71.59^{b} \pm 0.50$ & $*$ \\
\hline Liver \% & $2.88 \pm 0.04$ & $2.83 \pm 0.25$ & $2.29 \pm 0.23$ & $2.45 \pm 0.04$ & $2.79 \pm 0.34$ & NS \\
\hline Gizzard \% & $1.89^{\mathrm{a}} \pm 0.09$ & $1.54^{\mathrm{b}} \pm 0.09$ & $1.48^{\mathrm{b}} \pm 0.02$ & $1.58^{\mathrm{b}} \pm 0.03$ & $1.43^{\mathrm{b}} \pm 0.02$ & $*$ \\
\hline Heart \% & $0.54 \pm 0.04$ & $0.49 \pm 0.01$ & $0.55 \pm 0.01$ & $0.53 \pm 0.01$ & $0.51 \pm 0.05$ & NS \\
\hline Giblets $* \%$ & $5.32^{\mathrm{a}} \pm 0.17$ & $4.87^{\mathrm{ab}} \pm 0.29$ & $4.33^{\mathrm{b}} \pm 0.25$ & $4.57^{\mathrm{ab}} \pm 0.04$ & $4.74^{\mathrm{ab}} \pm 0.37$ & $*$ \\
\hline Ready to Cook \%\# & $75.74^{\mathrm{b}} \pm 0.58$ & $76.44^{\mathrm{ab}} \pm 1.11$ & $78.62^{\mathrm{a}} \pm 0.11$ & $75.87^{\mathrm{b}} \pm 0.71$ & $76.33^{\mathrm{ab}} \pm 0.56$ & $*$ \\
\hline
\end{tabular}

Table (5): Prices (L.E./ Ton) of different experimental diets .

\begin{tabular}{lccccc}
\hline \multirow{2}{*}{ Items } & \multicolumn{5}{c}{ Dietary Treatments } \\
\cline { 2 - 6 } & Control & $\mathrm{T}_{1}$ & $\mathrm{~T}_{2}$ & $\mathrm{~T}_{3}$ & $\mathrm{~T}_{4}$ \\
\hline itarter (1-14) days & 6707 & 6755 & 6838 & 6886 & 6743 \\
Jrower (15-28) days & 6449 & 6497 & 6580 & 6628 & 6485 \\
inisher (29-35) days & 6199 & 6247 & 6329 & 6377 & 6235 \\
\hline *1- control $(C) . \quad 2-C+G A A\left(T_{1}\right)$. & $3-C+A A .\left(T_{2}\right)$. & $4-G A A+A . A .\left(T_{3}\right)$ & $5-C+\beta$-mananase $\left(T_{4}\right)$
\end{tabular}

Table (6): Effect of different dietary treatments on some economic traits.

\begin{tabular}{lccccc}
\hline \multirow{2}{*}{ Items } & \multicolumn{5}{c}{ Dietary Treatments } \\
\cline { 2 - 6 } & Control & $\mathrm{T}_{1}$ & $\mathrm{~T}_{2}$ & $\mathrm{~T}_{3}$ & $\mathrm{~T}_{4}$ \\
\hline Average feed intake (Kg) & $2.94 \pm 0.06$ & $2.91 \pm 0.06$ & $2.78 \pm 0.04$ & $3.60 \pm 0.04$ & $3.18 \pm 0.06$ \\
Feed Cost (LE) & $18.91 \pm 0.44$ & $18.83 \pm 0.42$ & $18.32 \pm 0.28$ & $23.71 \pm 0.32$ & $20.57 \pm 0.44$ \\
Total Cost (LE) \# & $31.91 \pm 0.44$ & $31.83 \pm 0.41$ & $31.32 \pm 0.28$ & $36.71 \pm 0.32$ & $33.57 \pm 0.44$ \\
Total Return (LE) * & $45.75 \pm 1.18$ & $47.79 \pm 0.54$ & $45.08 \pm 0.57$ & $58.33 \pm 0.72$ & $50.17 \pm 0.51$ \\
Net Return (LE) & $13.84 \pm 0.77$ & $15.96 \pm 0.15$ & $13.76 \pm 0.28$ & $21.62 \pm 0.39$ & $16.60 \pm 0.08$ \\
Economic Efficiency & $43.33 \pm 1.92$ & $50.14 \pm 0.42$ & $43.92 \pm 0.52$ & $58.88 \pm 0.56$ & $49.46 \pm 0.46$ \\
Relative Economic & $100.00 \pm 0.00$ & $115.73 \pm 0.98$ & $101.35 \pm 1.20$ & $135.89 \pm 1.29$ & $114.14 \pm 1.06$ \\
Efficiency & &
\end{tabular}

Efficiency

\# Total cost $=$ (feed cost + price of one-day live chicks + incidental costs $)$;

* According to the local price of Kg sold carcass which was $25.00 \mathrm{L.E}$.

" 1 - control $(C) . \quad$ 2- $C+G A A\left(T_{1}\right) . \quad 3-C+A A .\left(T_{2}\right) . \quad 4-G A A+A \cdot A .\left(T_{3}\right) \quad$ 5-C+ $\beta$-mananase $\left(T_{4}\right)$ 
Arafa et al. 